\title{
NÁRODNÁ HUDBA: NUTNOSŤ, ALEBO VOLBA? NIEKOLKO POZNÁMOK K HUDOBNÝM VZŤAHOM ČECHOV A SLOVÁKOV V OBDOBÍ PRVEJ ČESKOSLOVENSKEJ REPUBLIKY
}

\begin{abstract}
S největši dychtivostí čekali jsme odpověd’ na otázku po národnosti. „Jste Slovák? “ Nechápavý pohled. Až po jednu ves všude odpovídali: ,Hutorim po slovensky i po mad’arsky. “ „Nepytám sa, ako hutorite. Ale či ste Mad'ar, alebo Slovák. “Tu bylo obyčejně dlouhé vyjednávání. Ćlověk mèl slovenské jméno, dèti mluvili slovensky, tvár̆ slovenská - a nevědèl, zda je Slovák či Mad’ar.

Vynalezli jsme určitá kritéria: jak se modli s dětmi, jak mluví doma, z jakých knižek se modli (když umèl čist) a podobně, a dle toho jsme mu museli sami napsat národnost. Často zněla strašná odpověd': „A to šicko jedno! Ked' bude dobre mezi Mad'armi, su Mad'ar, ked' mezi Čechami, su Slovák."
\end{abstract}

František Peroutka, z faktov ohl'adom sčítania l'udu z roku 1919

\section{Národná hudba ako východiskový pojem pre skúmanie sociologicko-metodologickým postupom}

Národné povedomie je zakódovaným súborom v ktorého hraniciach sa pohybujeme.

V kolónke národnosti pri akomkol'vek dotazníku, či spočítavaní obyvatel'stva, sa daný adresát rozhoduje o príslušnosti k národu. Často si nekladie otázku doby vzniku pojmu národnosti, nie to ešte aby mu prikladal nejakú váhu, že tu nie vždy tento pojem bol, a že sa vyskytol len od určitej doby. Stávame sa totiž súčast'ou niečoho do čoho sme sa narodili, a čo pokladáme už za tak zautomatizované a jasné, že nad tým vôbec nepremýšl'ame a berieme to ako samozrejmost'.

Východiskom pre moje uvažovanie a základným bodom je národná špecifikácia v hudbe. Od istého obdobia v dejinách hudby totiž môžeme pozorovat' zvýšený záujem o nacionálne a národné prvky, vd'aka ktorým už dnes máme možnost' škatul'kovania.

1 PEROUTKA, František. Budováni státu. 1918 - 1919. Praha: Lidové noviny, 1991, s. 135. 
Ako vzniká objektívna realita? Aké postavenia má národ, ako pojem, jav a kedy a ako sa konštituoval? Má moje subjektívne stanovisko podiel na utváraní objektívnej reality? Východiskovým bodom bude pre mňa pojem internalizácie a intersubjektivizácie.

Internalizácia ako „bezprostředni vnímání či interpretace objektivní události jako události majici význam, tedy jako projevu subjektivnich procesủ jiného člověka, přičemž zároveň význam tohoto projevu přijmu subjektivně za sviojj.“2

Internalizace v obecném slova smyslu je východiskem nejprve pro porozumèní ostatním lidem a pak pro chápáni světa jako společenské reality, jež má určitý význam. ${ }^{3}$

Štruktúra je tvorená zásadou, že „chápu“ okamžité subjektivní procesy druhého člověka, ale i svět, v němž žije a který se stává mým vlastním světem. ${ }^{4}$

Národná hudba a jej ukotvenie sa tak dostáva zo svojej uzavretosti na výslnie a potrebuje objasnenie $\mathrm{z}$ hl'adiska hudobných štruktúr, ako aj historického zástoja. Ak chceme štruktúre porozumiet', mali by sme sa na ňu dívat' z nadhl'adu. To znamená byt' v nej vnútorne zasiahnutý, avšak vyjst' aj nad ňu a chápat' jej dôsledkom, príčinám a prostriedkom.

Ked' sa dívame na obraz národnej hudby, môžeme vidiet', že ju tvorila predstava, ktorá bola do značnej miery romantická, a to vo vtedajších potrebách národných „hlasov“" kodifikovat' nielen jazyk a politický systém, ktorý by umožňoval národné svoj bytie, ale aj obraz hudby, ktorá by bola špecifická pre daný národ. Nielen skladatelia, ale najmä intelektuálna spoločnost' konca devätnásteho storočia požadovala národnú hudbu s jej originálnymi prvkami ako ukazovatel', „toho čo je naše" a čím sme ako národ v hudbe charakteristický.

Vedenie je viazané na bytie. Nájdenie pomysleného mostu medzi dvojicou pojmov a národnou hudbou vedie skrz subjektívny zretel' každého jedinca. Hudba sa nedokáže oddelit' od procesu tvorca - dielo - recepcia, je ním utváraná a z hl'adiska recepcie tak ponúkaná spätná väzba. Daný rámec, ktorého metodologickú dialektiku opíšem nižšie, vytvára predpoklad pre cestu k vyjasneniu si pojmu národnej hudby.

Jav jednania sociálnych zložiek v spoločnosti odkazuje k činitel’om typizácie a habitualizácie, k externalizácii objektívnych tvrdení a postojov. Inštitucionalizácia sa tak zastrešuje a dochádza $\mathrm{k}$ subjektívnej internalizácii na základe ktorej sa vytvorí nový pojem či inštitúcia. Ako snád' podvedome tušíme internalizačný postup, za snahou vytvárania inštitúcí́, je určitou dialektickou obmenou a spevnením.

Metodologický postup by tak začínal na ujasnení si jednania ako východiskového faktu pre historiografickú orientáciu, to znamená zber bibliografie, informácií, slovníkových hesiel, určitá heuristika na základe konkrétnej problematiky.

2 BERGER, L. Peter - LUCKMANN, Thomas. Sociální konstrukce reality: pojednání o sociologii vědění. Brno: Centrum pro studium demokracie a kultury, 1999, s. 128. 
V našom prípade teda ujasnenie si nielen pojmu národná hudba, ale aj historické fungovanie národných škôl a teórie národa a štátu. Tol’ko od jednania, od javu.

$\mathrm{K}$ podstate a $\mathrm{k}$ fenoménu nás sprevádza d'alší krok, a to proces typizácie a habitualizácie. V metodologickom postupe muzikologického bádania by sa daná dvojica sociologických pojmov premietla k d'alšiemu stupňu a to $\mathrm{k}$ hl'adaniu určitých špecifických prvkov a povahy národnej hudby. To znamená analýza diel s prívlastkom národná, a kladenie si otázky, prečo práve tieto diela sú vhodné či mienené ako národné.

Externalizácia je tak nastolená požiadavkam definície konkrétnych výstupov, ktoré sa uskutočnili doterajším priebehom. V medziach dialektickej jednoty a spojitosti a z dosial' naznačeného metodologického postupu, sa tento bod uskutočňuje ako výstup pre doterajší výskum, ako určité polemizujúce bádanie. Dostávame sa totiž k bodu objektivizácie, a pred týmto bodom, ktorý obsahuje určitý výpočet súdov a objektívnych pojmov a výstupov, potrebujeme si ujasnit' stav doterajšieho heuristického hl'adania a analytického pohl’adu. V tomto štádiu nastáva hermeneutická rovina, ktorá je uskutočnená formou výkladu jednotlivých teórií národnej hudby, či špecifických sledov a postupov charakteristických, vyvodených z analytického zámeru, pre hudbu národa.

Po hermeneutickom výklade doterajších prístupných teórií, sme schopní objektivizovat' určité náčrty fungovania a podstaty javu národnej hudby. Práve $\mathrm{v}$ tomto bode kodifikujeme jeho začínajúce obrysy.

Inštitucionalizácia je tak verifikáciou objektivizačných snáh.

A napokon sa dostávame $\mathrm{k}$ hlavnému bodu a to $\mathrm{k}$ internalizácii, a ku subjektívnemu hodnoteniu a tvorbe nových teórií, k udržaniu, alebo jeho prípadnej korigácii. V mysli by sa dala vytvorit' akási konštrukcia, kde by tento bod viedol k určitému vrcholu myslenia a metódy. Ked’že sa však jedná o dialektický kruh a určitú spätost' aj tento bod nie je vrcholom, ale opät' vedie k začiatku, javu, jednaniu. To predpokladá neustálu obmenu, určitý druh vývojovej špirály, kde sa po ukončení jedného cyklu myslenia, posúvame na špirále myslenia prístupu k problematike o pozíciu vyššie či nižšie.

\section{Národná hudba skrz Gellnerovskú optiku}

Nacionalismus neni probuzením národi̊ $k$ sebeuvědomění, nacionalismus vynalézá národy tam, kde neexistuji. ${ }^{5}$

Benedict Anderson vo svojej knihe ${ }^{6}$ konštatuje, že „Gellner až př́liš dychtivě touži ukázat falešné záminky, za které se nacionalismus skrývá [...].7 Berúc do

\footnotetext{
5 GELLNER, Ernst. Thought and Change. Chicago: University of Chicago Press, s. 169.

6 ANDERSON, Benedict. Představy společenství. Úvahy o pưvodu a šírení nacionalismu. Praha: Univerzita Karlova v Praze, Nakladatelství Karolinum, 2008. 
úvahy fakty dvoch stanovísk, máme pred sebou dve hl'adiská berúce na seba pozornost' o vyvodenie záveru.

V krátkosti, Gellner vidí formujúci sa nacionalizmus v troch etapách spoločnosti, respektíve jeho nemožnú latentnú a prítomnú formu, a to v agrárnej, priemyslovej spoločnosti a tzv. veku prechodu k nacionalizmu. Anderson ho vidí v určitom kolektívnom povedomí, vôlu ku vzniku ako aj jeho kodifikovaniu. Funguje tu určitá „,nacionalistická predstavivost“" teda tá ktorá pretavuje predstavy o správnom fungovaní, do chovania a jednania.

Národná hudba. Môj vlastný zjednodušený vzt'ah fungovania národnej hudby je založený na dvoch predpokladoch. Ak funguje A, nepredpokladá fungovanie B, pretože predpoklad zlyhal na prostriedkoch. Záver argumentu? Nevhodné podmienky iných historických spoločenstiev nemohli zaistit’ akémukol'vek ,národnému povedomiu“" (A) životaschopnost', jednak z hl'adiska inej spoločenskej situácie, a iného stupňa vývoja, kde sa kládli iné priority.

Totiž fungovanie nacionalizmu (B) nemalo dostatočný stupeň pre rozvoj a čakalo v podvedomí spoločnosti. Vhodné podmienky v podobe, štiepenia a odporu voči doposial' nastavenej absolutistickej moci (či už monarchistickej alebo cirkevnej.) Zo „sociologického hl’adiska“ viedlo aj k vytvoreniu novej inštitúcie štátu.

Argument teda smeruje k opisu podmienok. Obrazne sa však prenesme do polovice devätnásteho storočia. Dôsledky priemyslovej revolúcie, ako aj tej Vel'kej francúzskej (1789) sú d’alekosiahle. Štát sa dokázal kodifikovat' na úroveň, kedy nielen zmazal pamät' tým, že sa vlastne vo svojom jadre len posunul na inú úroveň než doterajšie systémy. Podaril sa mu zaujímavý myšlienkový zlom, na ktorý l'udstvo čakalo. V rámci spoločenskej aktivity zoskupovania sa, sa štát etabloval ako útvar vyhovujúci podmienkam autority, dozorcu a nastavovatela spoločenskej normy.

Ako sa tento model spoločnosti preukazuje v hudbe? Je zaujímavé klást' si otázku Národnej hudby nie oddelene ale v súvise spoločenských situácií. Národná hudba funguje tam, kde je potreba identifikovania sa ako spoločenstva. Táto prostá definícia by bola jednosmernou, keby sa neposadil pojem národnej hudby do historického zástoja. Na príklade Slovenska sa dá totiž konštatovat', že hudba tu bola činorodou zložkou a hudba na území Slovenska, pestovanou či už nemeckým obyvatel'stvom, alebo duchovenstvom vel'mi vysoko rozvinutou.

Tu teda vidíme, že územie nezohrávalo hlavnú úlohu. Hlavnú rolu tu neskôr predstavoval pojem národ. Aký faktor sa však vyskytoval v spoločnosti, že sa vo vplyvnej vrstve predstavitel'ov toho - ktorého národa, táto potreba ako národ, národné kodifikovanie sa, stvorila a prebudila?

Vidiet' veci v súvise a s povzdychom ,všetko tu už bolo“ dotvára do spoločenskej zápletky trochu viac svetla. Nám doteraz prístupnom a nami interpretovanom obraze sveta odpoved' tkvie padá a vstáva na našom prístupe $\mathrm{k}$ fungovania sveta. A síce čase. Časový rozmer nás natol'ko ovplýva, že vidiet' všetky okolnosti lineárne spôsobuje, tú prazvláštnu potrebu škatul'kovania, formovania záverov spoločenských etáp a nie $\mathrm{v}$ poslednom rade odpovedí po otázkach fungovania melosu - étosu v hudbe. 
Nie je práve hudba schopnost' vnímat' veci inak? Hudobný čas predsa predstavuje časový úsek žijúci vlastný život nezávislý na našej predstave. Avšak popretie jednej l'udskej etapy, kde sa „existencia“ času uplatňuje ako naša predstava po vysvetlení, po zžívaní sa a žití vo svojej minulosti, vidiac budúcnost', je málo myslitel'ná. Nie je snád' schodnejšia interpretácia videnia pojmu národnej hudby ako osamotené simulakrum, predstavujúce výsledok jednej etapy, jednej myšlienky, jedného artefaktu spoločnosti?

Má zmysel hovorit' o národnej hudbe? Ked' vyberieme slovenský národ, čo ho tvorí? Máme tendenciu kolektivizovat'. Kol'ko nás je? Pät' miliónov a čo tí emigrovaní? Sú vlastne oni ešte príslušníkmi národa? Tu sa dostávame $\mathrm{k}$ dešifrovaniu, čo teda tvorí to špecifické, národné? Kultúra, jazyk, písmo, povedomie, zvyky?

Prečo hŕstka slovenských vzdelancov a inteligencie začala cítit' potrebu po slovenskej národnej hudbe? Bola naozaj slovenská národná? Ak totiž áno, čo ju tvorilo a z hl'adiska národa charakterizovalo? Ak ku národu patrili všetci čo hovorili slovensky, no bývali na salaši, stala sa ich pieseň, či hudba s ktorou sa stretávali národnou? Cítime, že nie. Musel teda nastat' určitý proces inštitucionalizácie a selekcie.

K záveru kapitoly. Naše vlastné presvedčenie, ako aj zanietenost' sú jedným z prostriedkov pre budovanie stavu národnej hudby. Záležalo už len od miery vplyvu. Nadarmo by sa sedliak na Orave namáhal nad národnostnou myšlienkou, avšak mysel' l'udí majúcich v rukách formovanie momentálnej dychtivosti, dokázala zožat' slávu v podobe termínov a definícií obt’ažkaných v literatúre.

Je to teda len konštrukt? Jedná sa o určitú ideu? Všetko ukáže čas, takisto aj to, či tá naša národná, slovenská nie je len jednou z hudieb, ktoré ňou môžu byt', a či spôsoby a praktiky ktoré sa pri nej uplatňovali, nie sú len jednými z možných.

\section{3. Česko-slovenské hudobné vzt'ahy}

Len to jed'inkuo ešte pripomenut' chceme, že hudba bola síce pekná, len že na Slovenskom divadle ustavičnje mad'arskej nuoti hrat'voláko nepristaňe, - ako kebi sme ňemali dost' utešenich slovenskích nuot! ${ }^{8}$

Vzt'ahy Čechov a Slovákov pred rokom 1918 poukazovali na nejasnost' spoločnej cesty, ktorá bola zo strany niektorých Čechov podporovaná predstavou Karola Kálala (autora Na krásném Slovensku) mimochodom hojne píšuceho si s Masarykom. Ten sa okolo roku 1900 ked' vzniká realistická, l'udová strana o Slovákoch sa vyjadruje: „Co se poměru k Uhrám týče, uznáváme práva a zvláště kulturni a hospodárské poměry zemí koruny sv. Štěpánské, ale nemůže nám být lhostejno, že národové uheršti a zejména větev našeho národa, Slováci, jazykově, národnostně a kulturně všemožně jsou zkracováni a př́mo potlačováni. ${ }^{“ 9}$

8 Slovenskje Národňje Novini, roč. 3, 30. marca 1937, č. 173, s. 691.

9 STEHLÍK, Michal. Češi a Slováci. 1882-1914. Nezřetelnost společné cesty. Praha: Togga, 2009, s. 37. 
Práve spomínaný Karol Kálal zohrával obrovskú úlohu československej jednoty založenej roku 1896. Roku 1906 vychádza jeho kniha Proč se o Slováky staráme, kde mimo iného píše: „Slováci samo o sobě jsou národ malý a nezámožný, $i$ kdyby nebyli utlačováni, nestači na mohutnou kulturu a nezbývá jim, nežli se opřiti o některý sousední národ četnější a vzdělanějši a žili s ním. ${ }^{10}$

Niet divu že rôzne Kálalove vyjadrenie vzbudili negatívny ohlas zo strany slovenskej inteligencie. Napokon aj konečné Kálalovo povzdychnutie je toho dôkazom: Česká láska ke Slovensku je ojedinělý úkaz na Slovanstvu, ba ojedinělý úkaz $v$ dějinách evropských, jakož také slovenské neporozumění je ojedinělé.

Dôkazom československej spriaznenosti je aj Kálalova publikácia Jdète na Slovensko!, ktorá podtrháva význam viditel'nosti Slovenska ako prostriedok ,léčby malomyslnosti, do jakéž jej strhuje zvláště Videň a blizkost Prahy k německéти území $\left[\ldots . .{ }^{11}\right.$

Ako konštatuje Ladislav Burlas, je známe, že pri budovaní profesionálnych základov slovenskej hudobnej kultúry pomáhala celá skupina českých hudobníkov. „Spomeňme aspon̆ Milana Zunu, Oskara a Karla Nedbala [...]. Uved'me pedagógov Hudobnej a dramatickej akadémie, ako boli Gustáv Náhlovský a Norbert Kubát, dirigentov Milana Zunu, Františka Dyka, Josefa Vincourka [...], muzikológa Dobroslava Orla, hudobných kitikov Antonína Hořejša, Jindřicha Květa, skladatel'ov Oskara Nedbala, Zdenka Folprechta, Emanuela Maršíka a Miloša Smateka, Emila Axmana [...]. ${ }^{12}$

Čím je českému člověku Slovensko? Není pro českého ducha krásnějšiho a významnějšiho útočiště a atmosféry, jež by více silila, výšila, více jistoty dala, více zúrodnění. Na Slovensko se jde pro poznání, porozumèt sobě a náležet sobě. Slovensko je zem, kde je více zjevư věčných než dočasných, a velké věčné harmonie budí a rozvíjí. Nechápu českého umèlce, který není pouhým artistním člověkem, nýbrž bytostí kultivovaných smyslů a vřelého duchovního citového života, který by se nevrátil z této zemé, kde proud věčnosti plyne tak silným, prudkým tokem, $z$ těchto krajin zalitých, pohlcených dechem hor a obrovských obzorù do naši kultury, do našeho života je rozkolník, prepodstatněn, s hořkým vnitřním osvobozenim. ${ }^{13}$

Emil Edgar

Ako popísat' vzt'ah dvoch blízkych národov? Kde sa môžu rozpoznat' opravdivé ohnivká charakteristiky vzt’ahu vtedajšieho obdobia? Z metodologického

10 STEHLÍK, Michal, op. cit., s. 50.

11 HRČKOVÁ, Nad'a. Tradicia, modernost' a slovenská hudobná kultúra. Bratislava: Litera, 1996, s. 29.

12 BURLAS, Ladislav. Pohl'ady na súčasnú slovenskú hudobnú kultúru. Bratislava: Opus, 1987, s. 89.

13 POTÚČEK, Juraj. Za slovenskú hudbu a spev: (Antológia príspevkov, kritik a štúdii) / Alois Kolisek. Bratislava: SAV, 1968, s. 21. 
hl’adiska je vyššie spomínaný inštitucionalizačný proces - dejinami myšlienky. Ako zachytit' vzt’ah, myšlienku ako artefakt, na ktorý sa dívame, pozorujeme ho a dávame do súvisu s faktami? Čo ho tvorí?

Z môjho hl'adiska vidím pre rozvoj tohto spojeného metodologického prístupu vyostrenú vzt’ahovú situáciu, čo vlastne znamená pozorovanie vzt'ahu v kontexte a vyhrotenej situácii. Dalo by sa namietnut', že hl'adanie len týchto ohniviek kde sa nejakým spôsobom dostali do konfliktu, či fungovali vedla seba vzt’ahy hudobné, či národnostné je pohl'ad ad absolutum jednosmerný. Avšak myslím, že práve vyhrotená vzt’ahová situácia je ukážkou pohybu daných pozorovaných elementov.

Ked' si napríklad vezmeme česko-slovenské hudobné vzt'ahy a budeme chciet' na nich aplikovat' daný postup, bude ma najmä zaujímat' otázka ako? Ako vstupuje do povedomia slovenská hudobná moderna? Ako sa buduje fikcia národnej hudby Slovákov a ako pôsobí na Čechov?

Z hl'adiska zástoju tohto obdobia vidím ako relevantnú cestu príklon ku výkladu dejín ako neustáleho procesu utvárania a vytvárania myšlienky/ideje. Z historického kontextu totiž nemám $\mathrm{v}$ úmysle kauzálne popisovat' chronologické udalosti, ale môj zámer pre metodologickú predlohu skúmania daných vzt’ahov Čechov a Slovákov je zámer, ktorý obsahuje otázky historických súvislostí, aplikovatel'ných do hypotéz: a síce politicko-spoločenské tézy:

1. Identita občanov útvaru prvej československej republiky

2. Národnostná myšlienka $\mathrm{v}$ spoločenských programoch

3. Národný štát verzus štát národnostný? a ku vzt’ahom hudobným, tézy:

1. Ako sa utvorila myšlienka národnej slovenskej hudby a čo ju tvorí?

2. Ako sa národná slovenská hudba prezentovala a o čo usilovali národní skladatelia?

3. Bola slovenská hudobná moderna tridsiatych rokov prirodzeným vyústením snáh skladatel’ov, alebo pojem zaručujúci vyrovnávanie sa s českou kultúrou?

Rôzne diskusie priniesli rôzne východiská. Čo sa ale počtu hudobne vedeckých konferencií na tému česko - slovenských vzt’ahov týka (1918-1938) nedá sa im upriet' akási milá, láskavá konfrontácia, čiastočne niekedy podporovaná životaschopnými poznámkami.

Na slovenskú hudbu tohto obdobia je z hl'adiska muzikologickej reflexie nahliadané z pohl'adu optiky skladatel'ov (Frico Kafenda, Oto Ferenczy, Fraňo Dostalík), českých osobností s dosahom na Slovensko (Emanuel Maršík, Nedbalovci, Kolísek) českých pedagógov i českých skladatel’ov s dosahom na slovenskú hudbu (Novák, Suk, Hába) a najmä Zicha.

Klasické východiská a analýza podmienok na Slovensku zavádza k tomu, že pred devätnástym storočím tu prakticky slovenská hudba neexistovala. To je však mylné, pretože hudba na území Slovenska bola živou, a to, že devätnáste storočie počnúc venčekármi prinieslo rozmach významu l'udovej piesne a dôraz 
na rýdzo slovenské prvky (Ktoré to sú?) len potvrdilo živnost' hl'adania národnej hudby.

Zdenko Nováček: „Masarykizmus, najmä jeho konzervativizmus, nesporne ul'ahčil nadväznost' českej a slovenskej hudby na staršie tradicie a umožnil revolučný prechod od minulosti $k$ vtedajšej pritomnosti." Ohl'adom konkrétnej reflexie slovenskej nastupujúcej generácie píše: „Nebola to však len osobnost' Vitězslava Nováka, ktorá prit’ahovala vtedajšiu slovenskú mladú generáciu, ale celková stabilita, rozhl'adenost', sformovanost' a relatívna výhodnost'vtedajšich českých moderných autorov pritahovat' $k$ sebe a učit'svojich mladších slovenských kolegov kompozičnému umeniu." ${ }^{\text {"14 }}$

Kolísek vidí v slovenskej piesni ,zdroj živé vody“a jej význam dokladá novelou S. H. Vajanského „Husla“, kde mimo iného píše: „Je to vel'ká nesmrtel’ná pieseň, ktoré náležite pochopit', objat', ocenit' môže len čisto slovanský duch." Okrem iného v uvedených textoch píše: „Není celé Slovensko stejně zpěvné. Čím více na východ, tím pưvodnější, rázovitějši je melodie, tím hlubší, tím jímavější je slovo lidové písně. V západních, na Moravě a jiných částech Rakouska z této strany přilehlých krajin Slovenska, jeví se i v písni lidové již vliv politického života, národního uvědomování [...] Jako všude, tak i na Slovensku jeví se vliv nové kultury a změněných sociálních poměrü - úbytkem zpěvu lidového u lidu i inteligence, jenž není sice tak veliký a rychlý jako napřiklad v Čechách, ale přece je patrný. Přesto však Slovensko ještě dlouho a dlouho zůstane zpěvavým a proto $z$ duše voláme: Jděte za písni slovenskou, jděte na Slovensko!"15

Celé hnutie okolo prebudenia a zaostalosti Slovákov v oblasti národného povedomia je príčinou: „Ked’že slovenský človek bol systematicky vychovávaný, že on nie je synom národa, ale len necennej, zaostalej, neschopnej ,národnosti ' - ked’ pri každom kroku počul na svoj rod odporné nadávky, podlé poznámky a ošklivé porekadlá - je psychologicky pochopitel'né, že sa so svojím rodom nevystatoval $v$ pasívnej rezistencii: hanbit'sa - nehanbil, ale že by sa hrdo bil v prsia, $k$ tomu nemal dost'vedomosti a vzdelanosti. On si rád zanôtil piesne, i národné si spieval, ale nie z národného cítenia, lež len zo spevavosti.“16

Anton Kompánek

V prvorepublikovej situácii podlomeného slovenského hudobného vedomia a sebavedomia bol konečne vel'kým počinom koncert 20. marca Spolku slovenských umelcov spolu s pražským speváckym spolkom Hlahol: Slovenský koncert v Prahe v Smetanovej sieni. Prítomný Nejedlý, ktorý sa vyjadril, že ,celkový ten

14 NOVÁČEK, Zdenko. Spoločné črty slovenskej a českej hudby v samostatnom štáte po roku 1918 a v socialistických podmienkach. In Česká a slovenská skladatelská tvorba vo vzájomnej kontinuite a ovplyvneni (1918-1983). Bratislava 1984, s. 5, 6, 7.

15 KOLÍSEK, Alois. Význam a umělecké zpracování slovenské písně lidové. In Slovenská čitanka. Moravsko- slezská beseda v Praze, 1911, s. 339-358.

16 KOLÍSEK, Alois. Národné povedomie Slovákov v ich piesňach. Vídeň: Melantrich, 1922. 
obraz ukázal, že slovenská hudba není tak chudá, jak se často ř́ká [...]. ${ }^{17} \mathrm{~V}$ Slovenskom denníku okrem iného Emil Axman píše: „20. marec bol historickým dňom pre slovenskú hudbu, po prvý raz vystúpili v Prahe pred českou verejnostou korporativne slovenski umelci (hudobný odbor). Historický význam tejto udalosti bol zosilnený pritomnostou prezidenta a protektorátom ministerstva školstva a národnej osvety $[\ldots] .{ }^{\text {“18 }}$

Z autentických slov Aloisa Kolíska z uvedeného koncertu: „Slovenská hudba prichádza dnes medzi vás [...]. Áno, uponižená Popoluška prichádza ku svojmu princovi, osloboditelovi, zabúdaná sestrička k bohatému českému bratovi, opustené diet'a $k$ svojej mamičke, $k$ matičke Prahe. Keby za mad'arskej vlády bol slovenský umelec otvorene pristúpil k Prahe, nuž bolo by to považované za vlastizradu. Dnes keby slovenski umelci nechceli pristúpit’ $k$ spoločnej matičke Prahe - to by bola zrada. Je svätou povinnostou spájat' sa vzájomnou srdečnost'ou, úprimnostou, obet’ou. Ja viem, že je potrebná unifikácia zákonov, ale potrebnejšia je unifikácia duš́ [...]. Náš slovenský koncert chce byt' toho ukážkou.“19

Spomínaný bojovník Alois Kolísek, ktorý pripisoval vel'ký význam najmä osobnosti Jána Levoslava Bellu, ktorého $\mathrm{v}$ článku $\mathrm{k}$ jeho jubileu ${ }^{20}$ vidí nielen ako skladatel'a, ale aj spisovatel'a. A práve tu začína akási poloha diskurzu o slovenskej národnej hudbe. Bellove články Naša hudba a spev, ${ }^{21}$ Slovanská hudba a zpěv slovenský, ${ }^{22}$ Podmienky a základy národnej hudby slovanskej, ${ }^{23}$ a najmä dôležité Myšlienky o vývine národnej hudby a slovenského spevu ${ }^{24}$ sú textami kde Koričánsky konštatuje, že Bella sa pridržiaval konzervatívneho náhl’adu: slovanskú hudbu možno obrodit', alebo národná hudba dá sa stvorit' na základe l'udových piesní. ${ }^{25} \mathrm{Na}$ tento článok reagoval o niekol'ko desat'ročí, avšak s neutíchajúcim hl'adačstvom po slovenskej národnej hudbe Ladislav Burlas. ${ }^{26}$ Kresánek situáciu zo začiatku 20. storočia reflektuje v článku Roky 1909-1918 v slovenskej hudbe. ${ }^{27}$

Na príklade bývalého Prešporku je vidiet' výmenu niekol'ko generačne stabilnej multietnickej spoločnosti. Od vyrovnania roku 1867 sa ku nemeckej väčšine pridružuje pomad'arčovanie. Čo bolo badat' jednak na spoločenskom živote ako

17

Smetana, 29. marca 1920.

POTÚČEK, Juraj, op. cit., s. 51.

POTÚČEK, Juraj, op. cit., s. 27.

KOLÍSEK, Alois. Ján Levoslav Bella. In Slovenské pohl'ady, 1923, roč. 39, č. 9, s. 529-542.

Slovesnost', II, 1864.

Dalibor, 1869.

Hudení listy, 1872.

Letopis Matice slovenskej, 1873.

KORIČÁNSKY, Gustáv. Ján Levoslav Bella. In Slovenské pohl’ady, 1923, roč. 39, č. 9, S. 529-542.

BURLAS, Ladislav. Myšlienky o vývine národnej hudby. In Slovenská hudba 1957, č. 2, s. 54-61.

In Slovenská hudba, 1967, roč. 11, č. 4, s. 157-161. 
aj v divadle, kde sa odohrávali nemecké a mad'arské predstavenia. Tieto dve sprvu „proti“" menšiny sa však v období okolo rokov 1918-1919 ocitajú v opozícii oproti novému spojeniu: ,politický vývoj sledujú s horkost’ou a spoločné položenie ich zbližuje. Československý tábor je ovel'a menej jednotný: nezanedbatel'ná čast' Slovákov, najmä prívržencov Slovenskej l'udovej strany, hodnotí politiku Čechov na Slovensku ako kolonialistickú a považuje za potrebné bojovne vystupovat' proti idey československého národa a politickému čechoslovakizmu." ${ }^{28}$

Majúc na mysli tak rok 1918, žiada sa doplnit', že smerom k vyvrcholeniu spoločného štátneho útvaru boli roky intenzívneho vzt’ahu 1908 - 1914. Či už je to rola slovenských študentov v Prahe, alebo aktívna slovenská politika (Andrej Hlinka) a napokon nie úplná znalost' slovenského prostredia, ktoré vzhl'adom tisícročnému začleneniu sa v Rakúsko - Uhorskej monarchii malo radu zvláštností.

V období prvej československej republiky je prílev českej inteligencie na Slovensko bohatý. Vznikajú klúčové inštitúcie, zakladá sa Univerzita Komenského, ako nasvedčujú dobové materiály bola českou univerzitou, ktorej prednášajúci jazyk bol čeština a vyučovaný slovenský jazyk podliehal idey československého národa.

A práve tu sa naráža na kameň úrazu. Ako sa podiel'ali Česi na formovaní novej slovenskej identity? Neposkytovali mu medvediu službu? Bola naozajstnou pomoc voči Slovákom v zmysle staršieho brata? A čo tá naša hudba slovenská národná?

Že český vplyv na slovenskú hudbu bol nesporný sú dôkazom aktivity Zicha pri teoretickom konštruovaní slovenskej národnej hudby. Jeho postuláty a požiadavky boli: skladatel', ktorý tvorí originálne diela, ktoré sú výrazom jeho osobnosti a je rodený Slovák, jeho diela sú slovenské, aj ked' sú vzdialené od prostej l'udovej piesne (obhajoba Kováča Wielanda ako diela národného a ostrá kritika Figušovho Detvana pre absenciu skladatel'skej originality a profesionalizmu.) Požiadavka aby skladatel', usilujúci o vytvorenie národnej hudby, sa musí primknút' v umeleckej technike $\mathrm{k}$ súčasnému štádiu hudby (ako vzor Novák) a napokon je potrebné, aby sa autor vyvaroval púhych časových experimentov. ${ }^{29}$

Pečman uvádza, že „Zich za nejslovenštějšiho skladatele považuje Vitězslava Nováka, který dovedl přetavit prvky slovenské lidové pisně a který také celý svi̊j kompozični projev provanul jeji rytmikou a melodikou. Ďalej Pečman hodnotí: „neubráníme se dojmu, že Zich chápal slovenskou hudbu jen jakousi ,odnož‘ hudby české a jen za součást tzv. hudby československé. V tomto smyslu byl Zich nositelem myšlenky o tom, že česká hudba je nadřazena hudbě slovenské. ${ }^{30}$

28 ZVARA, Vladimír. Hudba a hudobné divadlo v Bratislave pred prvou svetovou vojnou a po nej. Aspekty a súvislosti. In Príspevky k vývinu hudobnej kultúry na Slovensku. Bratislava: Univerzita Komenského v Bratislave, 2009, s. 77.

29 PEČMAN, Rudolf. Vladimír Helfert. Brno: Nadace Universitas Masarykiana, 2003, s. 79 80. (preklad T. Š.)

30 PEČMAN, Rudolf, op. cit., s. 109. 
Helfert na rozdiel od Zicha konštruuje náhl'ad na slovenskú hudbu ako vymedzenie a porovnanie sa s európskym kontextom, čo u Zicha chýba, a dá sa povedat', že Slovenskú hudbu vidí ako „podkategóriu hudby českej.“ Helfert naproti tomu hodnotí situáciu na Slovensku v Českej modernej hudbe: „Na Slovensku $v$ době před převratem nebylo vhodných podmínek, aby tam vyrostla samostatná hudebni tradice slovenská. Bylo třeba, aby přirozené hudebni nadáni Slovákü, dosvědčené ojedinělým bohatstvím lidové písně a její impulsivní i hlubokou emocionálností, bylo svedeno do nějakého kulturního střediska, $v$ němž by soustavnou praci několika generaci se vytvorila pi̊da, z niž by mohly vyrůst nové květy hudebni kultury slovenské.“31

Íst' od konca nastolených otázok a to hlavne k zámeru čiže formulovaniu slovenskej národnej hudby, je namieste otázka vzdelávania vtedajšej inteligencie a neskorších predstavitel'ov slovenskej národnej hudby. Pri počúvaní Novákovej skladby $V$ Tatrách, sa jej nedá upriet' monumentálnost', akási posvätná úcta $\mathrm{k}$ symbolu národa pod Tatrami. $Z$ počutého máme čo dočinenia s materiálom ktorý vonkoncom nepôsobí izolovane voči symbolickej rovine nejakého baču na salaši, či prostého slovenského pastiera. Naopak stretávame sa tu so sebavedomým materiálom, romantického razenia $\mathrm{s}$ dynamickým priebehom. Skladba vznikla v roku 1902, v revízii roku 1907. Suchoň bol Novákovým žiakom v rokoch 1931-1933. Kontroverznou otázkou je: Nevznikala slovenská národná hudba v Prahe a nedával sa jej charakter, navzdory predstavám slovenskej inteligencie, život na území Čiech?

\section{Záver}

Idea staršieho brata na Slovensku, či idea čechoslovakistická sú dôkazom prežívania a následného prenikania do spoločenského myslenia danej doby. Idea národnej hudby je akýmsi povedomím, ktoré nielenže dáva k prežitiu svoj vlastný produkt, ale uchováva v mysli l'udí akúsi povinnost' voči nemu. Tá spočíva vo vytváraní nových pomníkov zosobňujúcich epochy, v ktorých prevládajúca idea plnila úlohu akéhosi spoločenského sna. Idea sa stala zmyslom pre vytváranie fikcie, akurát prezlečenej za reálny a aktuálny problém svojej doby.

Tento fakt vidiet' na premene hl'adačstva $\mathrm{v}$ slovenskej muzikologickej spisbe. Kým u Bellu je jasná myšlienka národnej hudby, jej vzniku a apelu na ňu, u prvorepublikových osobností je národné prítomné taktiež, ale ako forma vyrovnávania komplexu Slovákov voči svetu. Odtial' aj vznikajú bizarné prirovnania slovenskej hudby ku kvetom na lúke, či iné obrazy, ktoré v skutočnosti hmlia a odvádzajú od základného ciel'a vystihnút' pravú podstatu problému Slovákov.

31 HELFERT, Vladimír. Česká moderní hudba: studie o české hudební tvořivosti. Olomouc: Index, 1936, s. 123-124. 
Po roku 1918 a etablovaní sa tzv. slovenskej hudobnej moderny, je d’alším zastavením vo vývoji hl'adanie špecificky slovenského voči najmä európskej moderne a Čechám, Pol'sku, ktoré majú na tvorbu týchto skladatel'ov najväčší vplyv.

A po roku 1945 môžeme opät' vidiet' vieru v ideu a honbu za slovenskou hudbou a otázkou, aká ona vlastne je?

Po krátkom exkurze a náčrte spomenutých línií je predložený text/úvod vstupom do pojednávania o národnej hudbe národa, ktorý sa vyznačuje rôznymi syndrómami. Na jednej strane údel, na druhej viera vo vít'azstvo. Vo vít’azstvo čoho však sa bojuje $\mathrm{v}$ podstate od začiatku prebudenia národa až po celý priebeh nebolo vždy jasné. Možno je to aj tým, že ideje za ktoré sa horlí majú charakter vel'mi premenlivý a ten sa zmenit' nedá, ten je v povahe. Spoločnosti i jednotlivca.

Tatiana Škapcová (tatianaskapcova@gmail.com), Ústav hudební vědy, Filozofická fakulta, Masarykova univerzita, Brno, CZ.

\section{ABSTRACT \\ NATIONAL MUSIC: NEED OR CHOISE? SOME NOTES ON THE MU- SICAL RELATIONSHIP OF CZECHS AND SLOVAKS DURING THE FIRST CZECHOSLOVAK REPUBLIC}

This contribution follows the relationship of Czechs and Slovaks during the period of the first Czechoslovak Republic. At the same time it sees its task in approaching the issue of Slovak national music that has always played an important role as a concept that characterises the Slovak music of this period.

\section{Key words}

Slovak and Czech relationships, nation, national music, national idea, First Czechoslovak Republic

\section{Bibliography}

ANDERSON, Benedict. Představy společenství. Úvahy o pưvodu a šíření nacionalismu. Praha: Univerzita Karlova v Praze, Nakladatelství Karolinum, 2008.

BELLA, Ján Levoslav. Slovanská hudba a spev slovenský. Dalibor 8, 1869, s. 57-58, s. 65-66.

BELLA, Ján Levoslav. Podmínky a základy národnej hudby slovanskej. Hudební listy 3, 1872, S. 127-129.

BELLA, Ján Levoslav. Myšlienky o vývine národnej hudby a slovenského spevu. Letopis Matice Slovenskej, ročník 10, 1873, zväzok 2, s. 10-29.

BELLA, Ján Levoslav. Myšlienky o vývine národnej hudby. Hudobnovedný sborník I., 1953, s. 2048.

BERGER, L. Peter - LUCKMANN, Thomas. Sociální konstrukce reality, pojednání o sociologii vědění. Brno: Centrum pro studium demokracie a kultury, 1999.

BURLAS, Ladislav. Myšlienky o vývine slovenskej národnej hudby. Slovenská hudba 1, 1957, s. 245-258.

BURLAS, Ladislav. Ku genéze slovenskej hudobnej moderny 1928-1939. Slovenská hudba II, 1967, č. 7, s. 289-293. 
BURLAS, Ladislav. Realistické tradície slovenskej hudby. Martin, 1953.

BURLAS, Ladislav - Mokrý, Ladislav. 40 rokov slovenskej hudby. Slovenská hudba 1, 1957, S. 13-15.

BURLAS, Ladislav. Pohl'ady na súčasnú slovenskú hudobnú kultúru. Bratislava: Opus, 1987.

ČAPKOVÁ, Kateřina. Češi, Němci, Židé? Národní identita Židi̊ v Čechách 1918 až 1938. Praha Litomyšl: Paseka, 2013.

Česká a slovenská skladatelská tvorba vo vzájomnej kontinuite a ovplyvnení (1918 - 1983) Bratislava, 1984.

Eugen Suchoň v kontexte európskej hudby 20. storočia. Bratislava: Národné hudobné centrum, 1998.

GELLNER, Arnošt. Národy a nacionalismus. Praha: Hř́bal, 1993.

HELFERT, Vladimír. Česká moderní hudba: studie o české hudební tvořivosti. Olomouc: Index, 1936.

HRČKOVÁ, Nad'a. Tradícia, modernost'a slovenská hudobná kultúra. Bratislava: Litera, 1996.

HROCH, Miroslav (ed.) Pohledy na národ a nacionalismus. Praha: Sociologické nakladatelství, 2003.

HROCH, Miroslav. Národy nejsou dílem náhody. Př́činy a předpoklady utváření moderních evropských národì. Studijní texty, Praha: Sociologické nakladatelství, 2009.

KOLÍSEK, Alois. Za písni slovenskou. Naše Slovensko 1, 1907/1908.

KORIČÁNSKY, Gustáv. Hovoríme o slovenskej hudbe. In Slovenská prítomnost literární a umělecká. Praha, 1931, s. 223-242.

PEČMAN, Rudolf. Vladimir Helfert. Brno: Nadace Universitas Masarykiana, 2003.

PEROUTKA, František. Budováni státu. 1918-1919. Praha: Lidové noviny, 1991.

POTÚČEK, Juraj. Za slovenskú hudbu a spev: (Antológia príspevkov, kritík a štúdií) / Alois Kolísek. Bratislava: SAV, 1968.

POTÚČEK, Juraj. Súpis slovenských hudobnoteoretických prác. Bratislava, 1955.

POTÚČEK, Juraj. Súpis slovenských nenotovaných spevnikov 1585-1965. Martin, 1967.

STEHLÍK, Michal. Češi a Slováci. 1882-1914. Nezřetelnost společné cesty. Praha: Togga, 2009.

STEHLÍK, Michal. SLOVENSKO. Země probuzená 1918-1938. Praha: Academia, 2015.

ZICH, Otakar. O rytmu tanečnich pisni slovenských. Hudba 1, 1920, s. 2-5, 72-75, 106-108, 118 120.

ZICH, Otakar. O slovenské pisni lidové. Slovenské pohl'ady 42, 1926, s. 754-758. 
